\begin{tabular}{lll} 
VOLUME 9 & No. 1, 22 Desember 2019 & Halaman 1-85 \\
\hline
\end{tabular}

\title{
Problematika Pengembangan Padi Organik di Sawangan Magelang serta Peluang Sertifikasi Internasional
}

\author{
Problems of Organic Rice Development in Sawangan Magelang \\ and International Certification Opportunity
}

\author{
*Subejo, Irham, Pinjung Nawang Sari, Arif Wahyu Widada, dan \\ Azizatun Nurhayati
}

Fakultas Pertanian Universitas Gadjah Mada, Bulaksumur Yogyakarta dan

Pusat Studi Asia Pasifik (PASP) Universitas Gadjah

Laksmi Yustika Devi dan Esti Anatasari

Pusat Studi Asia Pasifik (PASP) Universitas Gadjah Mada

Submitted: 07-11-2018; Revised: 28-01-2019; Accepted: 28-01-2019

\begin{abstract}
Organic farming has been remarkably evolving in many areas of Indonesia for responding environmental issues and producing healthy foods. Organic rice is a type of organic farming product of a system which has been widely practiced including in Sawangan Village Magelang District as one of pioneering area on organic rice development in Central Java Province. This study is directed to analyze supporting factors, various problems faced on the development of organic rice and opportunity for getting international organic certification. A study has been done through household interview (30 farmers), indepth interview with key informants and Focus Group Discussion (FGD) at agricultural office of Magelang District. Data analysis used in this study are statistical descriptive and categorical qualitative. Results of the study show that: (1) performance of organic rice gradually getting better and productivity level has been getiing closer to conventional high external input rice farming, (2) supporting factors on improvement of organic rice include healthy rice production initiated through integrated pest management, transformative group leadership, supports from related stakeholders, high economic incentive, improvement of market networking, product certification, ICT application and favourable natural resource endowment, (3) Problems faced on the development of organic rice include variety of product quality among farmers, price variety and fluctuation, difficulty in organic seed access, mixing area of organic and anorganic rice farming, (4) Strategies for improving opportunity to get international organic sertification include innovation on product diversification, application of fresh product certification, modernization of machine for rice processing.
\end{abstract}

Keywords: International certification; Organic rice; Problems; Sawangan; Supporting factors.

*Corresponding author: subejo@ugm.ac.id.

Copyright @ 2019 THE AUTHOR(S).This article is distributed under a Creative Commons Attribution-Share Alike 4.0 International license. Jurnal Teknosains is published by the Graduate School of Universitas Gadjah Mada. 


\begin{abstract}
ABSTRAK
Pertanian organik telah berkembang dengan pesat di banyak daerah di Indonesia untuk merespon berbagai isu lingkungan dan untuk memproduksi pangan sehat. Padi organik adalah jenis produk pertanian organik yang secara luas telah dihasilkan di Desa Sawangan Kabupaten Magelang sebagai salah satu desa perintis pengembangan beras organik di Provinsi Jawa Tengah. Kajian ini dilakukan untuk menganalisis berbagaifaktorpendukungdan problematikayang dihadapi petani padi organik dan peluang untuk memperoleh sertifikasi internasional. Kajian telah dilakukan dengan mewancarai 30 rumah tangga petani padi organik, in-depth interview dengan informan kunci dan FGD yang dilakukan di Dinas Pertanian dan Tanaman Pangan Kabupaten Magelang. Data analisis menggunakan statistik deksriptif dan kategorisasi kualitatif. Hasil kajian menunjukkan: (1) kinerja padi organik semakin membaik dan tingkat produktivitas mendekati padi konvensional yang menggunakan input luar tinggi, (2) faktor pendukung pengembangan padi organik mencakup: inisiasi sistem produksi padi sehat melalui Sekolah Lapangan Pengendalian Hama Terpadu (SLPHT) kepemimpinan kelompok tani yang transformatif, dukungan pemangku kepentingan, perluasan jaringan, pengujian/sertifikasi berbagai hal terkait produk, pemanfaatan teknologi informasi, dukungan potensi sumberdaya alam dan lingkungan, (3) Permasalahan yang dihadapi: variasi kualitas produk, fluktuasi harga antar kelompok tani, benih organik sulit diperoleh. Peluang dan strategi menuju sertifikasi internasional mencakup: inovasi diversifikasi produk, standarisasi produk dengan sertifikat Produk Segar Asal Tumbuhan (PSAT) dan perintisan dan modernisasi mesin pemroses beras yang berkualitas tinggi.
\end{abstract}

Kata Kunci: Faktor pendukung; Masalah; Padi organik; Sawangan; Sertifikasi internasional.

\section{PENGANTAR}

Gerakan dan pengembangan pertanian organik tidak hanya mendapat perhatian luas di negara-negara maju namun juga di negaranegara berkembang termasuk Indonesia. David dan Ardiansyah (2017) mendokumentasikan rangkaian historis terseleksi tentang perkembangan gerakan pertanian organik, sejalan dengan gerakan lingkungan di Indonesia yang dimulai dengan pembentukan WALHI tahun 1980, tergabungnya Indonesia dalam Pesticide Action Network Asia Pacific ( PAN-AP) tahun 1982, pendirian Bina Sarana Bakti yang didedikasikan untuk pertanian organik tahun 1984. Masyarakat Pertanian Organik Indonesia (MAPORINA) didirikan tahun 2000 dan secara formal pada tahun 2001 Kementerian Pertanian menerapkan program khusus pengembangan pertanian organik dengan slogan "Go Organic 2010". Pada tahun 2002 diluncurkan standar nasional untuk produk pangan organik (SNI 01-6729-202) yang direvisi pada tahun 2015 menjadi SNI 6729-2013 BioCert Organic Agriculture Organic Standard-ASEAN Standard for Organic Agriculture (ASOA) sebagai harmonisasi standar pertanian organik di negara-negara ASEAN.

Pengembangan pertanian organik dilatarbelakangi berbagai argumentasi penguat. Beberapa hal yang cukup menonjol adalah dampak negatif penurunan daya dukung lingkungan karena praktek pertanian dengan input eksternal tinggi yang bersifat eksploitatif serta menguatnya preferensi masyarakat global akan produk pangan yang aman dan sehat bagi konsumen. Sebagaimana dilaporkan oleh Jahroh (2010), ancaman kerusakan ekologis dan korban manusia karena pencemaran bahan kimia dalam praktik pertanian mendorong munculnya pertanian alternatif yang aman lingkungan yaitu pertanian organik.

Secara konseptual, IFOAM (International Federation of Organik Agriculture Movements) mendefinisikan pertanian organik sebagai sistem produksi pertanian yang holistik dan terpadu, dengan cara mengoptimalkan kesehatan dan produktivitas agro-ekosistem secara alami, sehingga menghasilkan pangan dan serat yang cukup, berkualitas dan berkelanjutan. Pertanian organik adalah sistem pertanian yang holistik yang mendukung dan mempercepat keanekaragaman hayati, siklus biologi dan aktivitas biologi tanah.

Terkait dengan praktik pertanian organik Azies menunjukkan bahwa pertanian organik menitikberatkan pada keterpaduan antara sektor pertanian dan peternakan dalam menjamin daur hara yang optimum (Azies dkk., 2014). Pertanian organik merupakan sistem 
pertanian yang bertujuan untuk tetap menjaga keselarasan atau harmoni dengan sistem alami dengan memanfaatkan dan mengembangkan semaksimal mungkin proses-proses alami dalam pengelolaan usaha tani.

Pengembangan pertanian organik khususnya beras di Indonesia selain memiliki peluang dan prospek yang cukup besar juga masih menghadapi berbagai kendala baik aspek teknologi produksi, pascapanen maupun promosi dan pemasaran produk. Berbagai strategi perlu dikembangkan dan diadopsi untuk untuk mereduksi berbagai kendala mempertimbangkan potensi ekonomi sangat terbuka atas pengembangan produk-produk organik. Supyandi mencatat dalam beberapa tahun terakhir bahwa kebutuhan beras organik baik di pasar lokal maupun ekspor dari tahun ke tahun juga terus berkembang. Potensi ekspor ke negara-negara ASEAN dan Timur Tengah sebesar 100.000 ton. Jumlah ini belum mencapai $10 \%$ dari kebutuhan pasar global. Pangsa pasar pangan organik di negaranegara Eropa, Oseania, Amerika Serikat, dan Kanada, diperkirakan akan tumbuh rata-rata sekitar 12,5 persen hingga tahun 2005. Pasar pangan organik di Asia Pasifik, seperti Jepang, Australia, Selandia Baru, Korea Selatan, dan Singapura, masih terbuka lebar. IFOAM juga menyebutkan bahwa tren permintaan beras organik di dunia tercatat cukup tinggi pada tahun 2011 (Supyandi dkk., 2014).

Mendasarkan pada perkembangan pertanian organik yang cukup pesat dan di sisi lain masih ada berbagai kendala dan problematika, nampaknya kajian tentang daya dukung dan problematika pengembangan padi organik serta bagaimana peluang memenuhi standar sertifikasi organik internasional pada level grass root menjadi isu yang strategis. Sertifikasi organik internasional menjadi perhatian yang serius karena menggambarkan pemenuhan terhadap standar internasional yang dapat memperkuat peluang dan daya saing menuju peningkatan nilai tambah dan perluasan jaringan pasar pada skala global.

Kajian ini diarahkan untuk dapat menganalisis daya dukung dan problematika pengembangan padi organik serta bagaimana peluang memenuhi standar sertifikasi organik internasional di Sawangan Magelang yang merupakan salah satu daerah pionir pengembangan pertanian organik di Provinsi Jawa Tengah.

\section{Metode}

Metode dasar yang digunakan dalam penelitian adalah metode deskriptif analitik dengan pendekatan campuran (mixed method) yang merupakan gabungan pendekatan kuantitatif dan kualitatif. Sedangkan teknik penelitian yang digunakan adalah survai.

Populasi dalam penelitian ini adalah petani padi organik di Desa Sawangan Kecamatan Sawangan Kabupaten Magelang Jawa Tengah. Pemilihan lokasi kajian dengan mempertimbangkan petani di Sawangan merupakan salah satu kelompok tani pionir di Jawa Tengah yang telah mengembangkan padi organik cukup lama dan mengalami kemajuan yang pesat dalam aspek teknologi budidaya dan pengelolaan maupun perluasan pasar produknya yang telah mencapai luar Pulau Jawa. Secara teknis, pemilihan sampel petani dilakukan secara acak sederhana sebanyak 30 petani.

Data dikumpulkan dengan menggunakan kuesioner terstruktur terhadap petani responden, observasi lapangan dan in-depth interview terhadap informan kunci yang terdiri dari ketua kelompok tani organik (GATOS) dan petugas penyuluh pertanian lapangan (PPL) serta dilakukan Focus Group Discussion di Dinas Pertanian Kabupaten Magelang. Analisis data dilakukan dengan menggunakan analisis statistik deskriptif dan analisis kategorisasi kualitatif.

\section{HASIL DAN PEMBAHASAN Kondisi Eksisting Pengembangan Padi Organik Di Sawangan}

Lokasi kajian merupakan sentra pengembangan beras organik yang secara administratif merupakan wilayah Desa Sawangan, Kecamatan Sawangan, Kabupaten Magelang, Provinsi Jawa Tengah. Posisi dan aksesibilitas Desa Sawangan sangat strategis dengan jarak desa ke ibukota kecamatan 3,7 km. Berdasar paparan Camat 


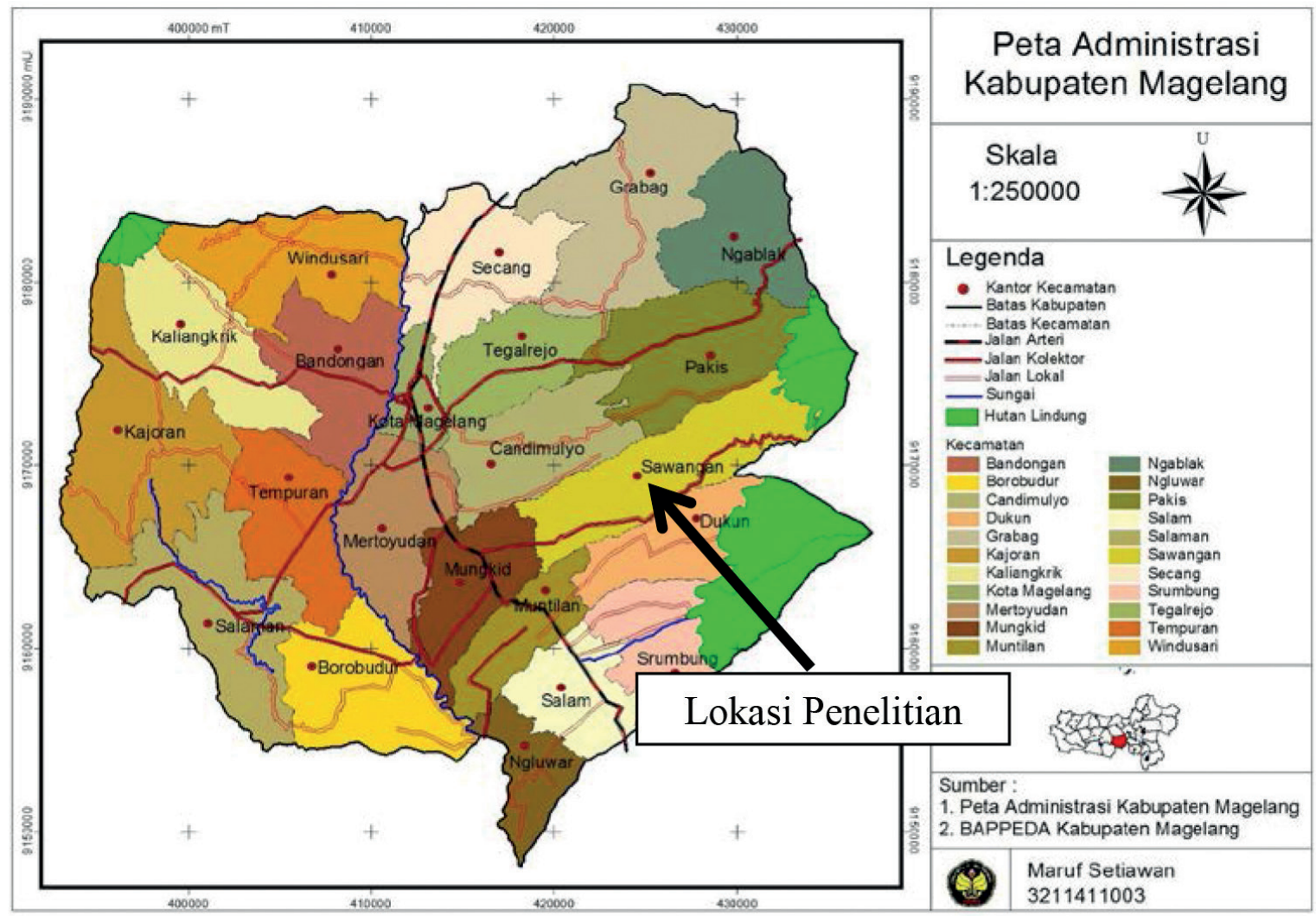

Gambar 1

Peta Wilayah Kabupaten Magelang (Sumber: Setiawan, 2013)

Sawangan (2018) tentang profil Kecamatan Sawangan, dinyatakan Desa Sawangan memiliki 15 dusun dengan jumlah kepala keluarga 1.417 dan total jumlah penduduk sebanyak 587 jiwa. Sektor pertanian masih merupakan sektor ekonomi yang dominan bagi masyarakat di Desa Sawangan dengan luas lahan pertanian 330 ha yang terdiri dari sawah 263 ha dan lahan pertanian non-sawah 67 ha.

Pengembangan padi organik di Sawangan berlangsung melalui proses bertahap dan mengalami dinamika sejalan dengan peluang dan prospek pengembangan serta problemproblem yang dihadapi oleh para pelaku usahatani organik dan pemangku kepentingan yang terkait. Budidaya padi organik di Desa Sawangan Kecamatan Sawangan Kabupaten Magelang secara prinsip telah dirintis sejak 2003. Perintisan awal dalam bentuk keterlibatan kelompok tani dalam Sekolah
Lapang Pengendalian Hama Terpadu dengan penekanan budidaya padi yang sehat dengan meminimalkan penggunaan petisida dan pupuk anorganik atau pupuk kimia. Tokoh petani pionir Bapak Soleh terlibat aktif dalam pengembangan Pengendalian Hama terpadu (PHT) yang dikelola oleh Laboratorium Lapangan (LL) Proteksi Tanaman Kedu. Berawal dari praktik PHT terus berkembang menjadi rintisan pengembangan pertanian organik dengan fokus pada padi atau beras organik.

Tahap lanjut dari perintisan usahatani padi organik di wilayah Kecamatan Sawangan Magelang telah berkembang menjadi Gabungan Tani Organik Sawangan (GATOS). Kondisi eksisting GATOS telah mendapat sertifikasi organik dan telah melakukan perpanjangan untuk siklus sertifikasi yang kedua. Proses pengajuan sertifikasi oleh kelompok mendapat dukungan dan fasilitasi 
dari mantri tani dan penyuluh pertanian lapangan (PPL) di Kecamatan Sawangan, Dinas Pertanian Kabupaten Magelang dan Dinas Pertanian Provinsi Jawa Tengah.

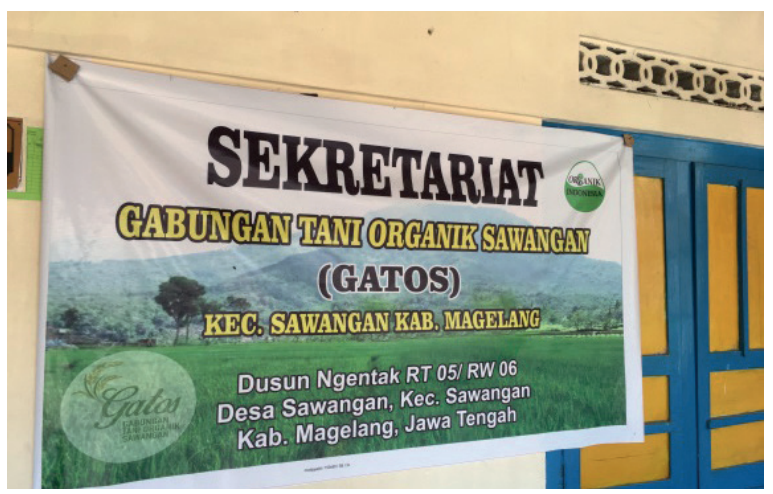

Gambar 2

Sekretariat GATOS Sawangan Magelang

(Sumber: Dokumentasi pribadi, 2018)

Implementasi PHT sebagai langkah awal pengembangan pertanian organik menekankan prinsip kebutuhan bahan makanan tumbuhan yang berasal dari berbagai material dan tidak hanya pupuk kimia. Prinsip budidaya pertanian sehat ini dijelaskan dengan rinci dalam SLPHT. Potensi risiko atas penggunaan pupuk kimia dan pestisida baik terhadap kesehatan tanaman maupun bagi lingkunganjuga menjadi perhatian yang serius dalam SLPHT. Penggunaan pupuk urea dalam usahatani yang telah dipraktikkan cukup lama oleh para petani secara bertahap terus dikurangi dengan penambahan bahan organik yang memadai.

Kelompok tani yang diketuai oleh Bapak Soleh, para petani anggota kelompok berlatih dan memproduksi pupuk kompos dan agensia hayati. Bahan-bahan dikumpulkan dari seresah, sampah organik serta pupuk kandang. Pada tahun 2015 dilakukan pembuatan pupuk kompos secara masal sebanyak 9 ton dan dibagikan secara gratis kepada anggota kelompok dengan alokasi sekitar sembilan karung untuk setiap petani. Selain aplikasi pupuk organik yang dibuat kelompok, juga dilakukan perbaikan $\mathrm{pH}$ tanah dengan penambahan dolomit bersama dengan aplikasi pupuk kompos.

Para petani dapat membuktikan, setelah dilakukan pengguaan pupuk organik, penambahan dolomit dan aplikasi agensia hayati, serangan organisme penggangu tanaman (OPT) sangat drastis berkurang dan tanaman padi menjadi lebih sehat. Aplikasi budidaya padi tersebut juga menyebabkan serangan hama wereng coklat yang selama ini menjadi masalah sangat serius bagi petani padi dapat ditekan dengan cukup efektif.

Anggota kelompok tani juga mengembangkan pupuk organik cair (POC). Penggunaan POC oleh petani terbukti efektif memperbaiki kualitas tanah dan dapat digunakan untuk mengendalikan hama walang sangit. Secara praksis, biasanya pada pagi hari petani mengumpulkan walang sangit di sawah, kemudian walang sangit ditumbuk dan dicampurkan dengan POC. Pencampuran POC dengan walang sangit cukup efektif untuk diaplikasikan pada tanaman padi.

Pertukaran informasi terkait dengan praktik PHT dan prinsip-prinsip pertanian organik dilakukan antar anggota kelompok tani dan dengan pengurus kelompok tani serta PPL yang secara regular melakukan pertemuan kelompok. Selain dilakukan pertukaran informasi dan pengetahuan antaranggota, pengurus dan PPL, juga dilakukan diseminasi informasi dalam keluarga baik melalui pembicaraaan dalam keluarga maupun saat praktik pengelolaan usahatani padi yang melibatkan anggota keluarga di sawah.

Prinsip budidaya dan pengelolaan padi dengan standar budidaya organik telah dimulai sejak tahun 2010. Saat ini kelompok tani GATOS telah memiliki sertifikasi padi organik dan telah diperpanjangan satu kali periode sertfikaasi. Jaminan standar organik juga secara bersama-sama disosialisasikan secara terus menerus pada anggota dan juga ada monitoring di antara rekan anggota kelompok tani sejawat (peership monitoring). Pengurus kelompok tani juga aktif memantau dan memberikan pendampingan baik dalam pertemuan kelompok maupun saat melakukan aktivitas di lahan persawahan.

Secara umum, penguasaan lahan padi organik oleh petani Sawangan Magelang cukup beragam. Perbedaan antara petani yang memiliki luas lahan terbesar dengan petani yang memiliki luas terkecil cukup tinggi, 
penguasaan lahan padi organik terkecil 940 $\mathrm{m}^{2}$ (tabel 1). Petani yang memiliki luas lahan garapan lebih dari satu hektar memiliki tipe penguasaan lahan dengan sewa dan hanya sebagian kecil yang termasuk milik sendiri. Keadaan ini menjadi kendala karena keputusan dalam pengelolaan lahan juga mendapat intervensi pemilik lahan.

Pengelolaan pertanian padi organik di Sawangan Magelang tergolong memiliki kualitas yang baik. Hal ini ditunjukkan dengan rerata produktivitas yang cukup tinggi walaupun produktivitas padi yang diusahakan oleh setiap petani cukup beragam. Rerata produktivitas padi organik lebih dari 4 ton per hektar. Petani dengan produktivitas padi organik yang tinggi adalah petani yang sudah mengusahakan padi organik lebih dari lima tahun. Faktor waktu ini sangat berpengaruh terhadap proses pengembalian unsur hara dan berbagai komponen lain dalam tanah sehingga lebih kaya nutrisi untuk penyediaan berbagai macam kebutuhan bagi tanaman untuk tumbuh dengan baik dan memproduksi hasil yang maksimal. Petani dengan produktivitas yang rendah umumnya petani yang baru saja mengusahakan padi organik kurang dari tiga tahun. Sebagian petani sedang melakukan proses pengembalian dan pengayaan unsur hara tanah dengan mengurangi berbagai macam input kimia dan mengganti dengan input yang lebih alami. Secara bertahap sejalan dengan perbaikan kualitas tanah, produktivitas akan naik mendekati produktivitas padi konvensional bahkan dapat melampauinya ketika kondisi berbagai unsur hara dalam tanah yang sangat majemuk telah tersedia.

Tabel 1

Profil Usahatani Padi Organik Tahun 2017 di Sawangan

\begin{tabular}{l|l|l}
\hline \multicolumn{1}{c|}{ Komponen Usahatani } & Komponen Perhitungan & \multicolumn{1}{c}{ Capaian } \\
\hline Penguasaan lahan $\left(\mathrm{m}^{2}\right)$ & Tertinggi & 18,000 \\
& Terendah & 940 \\
& Rerata & 5,567 \\
\hline Produktivitas (ton/ha/th) & Tertinggi & 8.0 \\
& Terendah & 2.8 \\
& Rerata & 4.7 \\
\hline Pendapatan (Rp/ha/th) & Tertinggi & $78,171,875$ \\
& Terendah & $6,496,278$ \\
& Rerata & $32,953,482$ \\
\hline Keuntungan (Rp/ha/th) & Tertinggi & $74,689,456$ \\
& Terendah & $-2,117,290$ \\
& Rerata & $26,661,009$ \\
\hline Pendapatan (Rp/usahatani/th) & Tertinggi & $78,561,429$ \\
& Terendah & $2,520,667$ \\
& Rerata & $19,047,594$ \\
\hline Keuntungan (Rp/usahatani/th) & Tertinggi & $78,423,929$ \\
& Terendah & $-3,811,121$ \\
& Rerata & $15,581,086$ \\
\hline
\end{tabular}

Sumber: Analisis data primer, 2018

Berdasarkan aspek pendapatan petani padi organik, petani memiliki pendapatan yang positif walaupun beberapa petani mengalami penurunan produksi, sehingga pendapatan berkurang akibat kerusakan tanaman karena hujan dengan intensitas tinggi. Meskipun pendapatan semua petani positif, tetapi jika dilihat dari keuntungan, masih terdapat petani 
dengan keuntungan negatif. Nilai keuntungan didapatkan dari pendapatan yang digunakan dengan berbagai biaya implisit di mana lahan milik sendiri dan tenaga kerja dalam keluarga yang sebelumnya tidak diuangkan maka semuanya dianggap sebagai biaya sebagai pengurang dari pendapatan yang sebelumnya sudah dikurangi berbagai biaya yang belum pernah dikeluarkan. Petani dengan keuntungan yang negatif adalah petani yang baru saja berusahatani organik dengan capaian produktivitas yang masih relatif rendah. Produksi yang rendah ini dibarengi dengan penggunaan input berupa tenaga kerja dalam keluarga dengan curahan yang cukup tinggi. Kondisi ini menunjukkan perlunya pembinaan dan pendampingan untuk meningkatkan kemampuan manajemen dan efisiensi usahatani padi organik.

Perkembangan pertanian organik umumnya masih mempunyai kendala internal yang berkaitan dengan petani yaitu kekuatiran petani terhadap penurunan hasil usaha tani mereka bila mengubah sistem budidaya padi dari nonorganik menjadi organik. Secara historis, terdapat penurunan produktivitas padi yang diusahakan oleh petani di Sawangan Kabupaten Magelang (Tabel 2). Keadaan ini merupakan hal yang wajar sebagai proses peralihan pertanian dari yang awalnya bertipe konvensional menjadi organik.

Tabel 2

Proses Capaian Menuju Usahatani Padi Organik di Sawangan

\begin{tabular}{l|l|l}
\hline \multicolumn{1}{c|}{ Komponen Usahatani } & Komponen Perhitungan & \multicolumn{1}{c}{ Capaian } \\
\hline \multirow{3}{*}{ Produktivitas konvensional (ton/ha/th) } & Tertinggi & 5.2 \\
& Terendah & 3.2 \\
& Rerata & 4.1 \\
\hline \multirow{3}{*}{ Produktivitas Proses Organik (ton/ha/th) } & Tertinggi & NA \\
& Terendah & NA \\
& Rerata & NA \\
\hline \multirow{2}{*}{ Produktivitas Rerata Sepanjang Penerapan } & Tertinggi & 4.7 \\
Organik (Rp/ha) & Terendah & 2.6 \\
& Rerata & 3.6 \\
\hline
\end{tabular}

Sumber: Analisis data primer, 2018

\section{Daya Dukung Sumberdaya Alam Dan Lingkungan Strategis}

Melaui in-depth interview terhadap ketua kelompok dan pionir pengembangan beras organik serta wawancara dengan petani responden, dapat disarikan beberapa isu strategis yang menjadi penjelas pengembangan padi organik tetap eksis dan pangsa pasar produk semakin berkembang.

a) Inisiasi sistem produksi padi sehat melalui dukungan dan praktik SLPHT

Praktik SLPHT padi yang dilakukan kelompok tani dengan supervisi dan pendampingan oleh ketua kelompok sangat kondusif bagi perintisan sistem pertanian padi organik karena prinsip-prinsip dasar PHT sangat sesuai (kompatibel) dengan prasyarat pertanian organik. Pengunaan bahan kimia baik pada pupuk maupun pestisida yang minimum secara bertahap dapat direduksi bahkan dapat mencapai level terendah atau tidak ada penggunaan bahan kimia.

b) Kepemimpinan transformatif dan inovatif dalam kelompok tani

Pertanian padi organik menuntut prosedur yang rinci dan dapat dilacak (tracebility) sehingga membutuhkan kekompakan dan kedisiplinan proses produksi dari pelaku usaha. Proses yang dapat memenuhi standar umumnya mudah dilakukan untuk produksi barang industri seperti di pabrik, tetapi cukup sulit dilakukan untuk 
proses produksi yang melibatkan orang banyak dalam suatu kawasan tertentu dan dikerjakan secara independen. Jaminan prosedur dan keberhasilan kelompok sangat ditentukan oleh kemimpinan transformatif dalam kelompok yang dapat selalu menghadirkan berbagai pengetahuan, ide dan inovasi baru bagi kelompk serta dapat memberikan contoh nyata bagi para anggota.

Pada Kelompok GATOS, figur Bapak Soleh sebagai ketua kelompok sangat efektif karena mampu memainkan peran leadership baik sebagai pengawas, koordinator, dinamisator dan organisator. Selain itu, Bapak Soleh juga mengelola lahan padi organik miliknya secara langsung seluas $3.000 \mathrm{~m}^{2}$. Melalui proses pengelolaan lahan padi organik secara langsung di lapangan oleh Bapak Soleh, juga memungkinkan para petani lain untuk belajar secara langsung dan bertukar gagasan melalui proses belajar sosial (social learning) sebagaimana dikonsepkan oleh Bandura (1977) di mana ada tokoh penting yang menjadi panutan dan berperan sebagai role model. Selain sebagai ketua kelompok, Bapak Soleh juga dapat melakukan monitoring dan mendorong para anggota untuk saling memonitor praktek usahataninya sehingga memenuhi standar praktik pertanian organik. Praktik peer monitoring yang ada di kelompok tani cukup efektif untuk menjaga kekompakan dan kepatuhan dalam kelompok yang mana hal ini dapat dimaknai sebagai pengembangan social capital sebagaimana digagas oleh Coleman (1988).

Kepemimpinan memiliki peran penting dalam mendorong pencapaian kinerja kelompok tani dan kepemimpinan yang transformatif dapat memfasilitasi kecepatan dan ketepatan pengambilan keputusan kolektif. Sebagaimana dilaporkan Ruslanjari (2017), akses terhadap sumberdaya, kekuatan dalam mengambil keputusan serta kualitas kepemimpinan dapat menguatkan proses pengambilan keputusan yang tepat di dalam suatu institusi.

c) Dukungan pemangku kepentingan terkait Dalam perkembangan usahatani padi organik, cukup banyak mitra atau partner strategis yang telah terlibat antara lain kementerian pertanian, dinas pertanian provinsi, dinas pertanian kabupaten, mantri tani, PPL, kelompok tani mitra, lembaga sertifikasi, LSM. Secara lebih rinci, jenis pemangku kepentingan, bentuk kontribusi, dan sifat kontribusi disajikan pada tabel 3.

Peran Mantri Tani dan PPL sangat penting dalam pengembangan beras organik. Berdasarkan indepth interview dengan Bapak Soleh diketahui mantri tani dan PPL Kecamatan Sawangan bernama Bapak Heru memiliki peran yang sangat penting pada tahap awal perintisan beras organik dimana mantri tani berperan sebagai pendamping lapangan sekaligus penghubung kelompok tani dengan pihak-pihak lain. Melalui mantri tani, pada awalnya dilakukan perintisan pemasaran produk beras organik pada para pegawai di Dinas Pertanian Kabupaten Magelang secara berkala dan juga di kantorkantor organisasi perangkat daerah (OPD) yang lain di lingkungan Pemda Kabupaten Magelang. Pada tahap selanjutnya setelah semakin dikenal, promosi produk dilakukan dengan dukungan teknologi informasi.

Tabel 3

Jenis Pemangku Kepentingan, Bentuk Kontribusi, dan Sifat Kontribusi

\begin{tabular}{l|l|l}
\hline Jenis Pemangku kepentingan & \multicolumn{1}{|c|}{ Bentuk kontribusi } & \multicolumn{1}{c}{ Sifat Kontribusi } \\
\hline Kementerian Pertanian & - Fasilitasi sertifikasi organik dan PSAT & Insidentil \\
& - Promosi produk & \\
\hline Dinas Pertanian Provinsi & - & Fasilitas sertifikasi organik \\
& - Promosi produk & Insidentil \\
\hline
\end{tabular}


Subejo, Irham, Pinjung Nawang Sari, Arif Wahyu Widada, Azizatun Nurhayati, Laksmi Yustika Devi, dan Esti Anatasari \& Problematika Pengembangan Padi Organik di ...

\begin{tabular}{l|l|l}
\hline Jenis Pemangku kepentingan & \multicolumn{1}{|c}{ Bentuk kontribusi } & Sifat Kontribusi \\
\hline Dinas Pertanian Kabupaten & $-\begin{array}{l}\text { Pendampingan, fasilitasi } \\
-\end{array}$ & Promosi produk/pameran \\
\hline $\begin{array}{l}\text { Mantri tani dan PPL } \\
\text { Kecamatan }\end{array}$ & $\begin{array}{l}\text { Penyuluhan dan pendampingan, promosi } \\
\text { produk }\end{array}$ & Regular \\
\hline Kelompok tani mitra & $-\begin{array}{l}\text { Koordinasi produksi dan pemasaran } \\
- \text { Pertemuan dan pelatihan }\end{array}$ & Reguler \\
\hline LSM & - Pendampingan dan advokasi & Insidentil \\
\hline Lembaga Donor & $-\begin{array}{l}\text { Hibah peralatan pemroses beras } \\
\text { berkualitas }\end{array}$ & Insidentil \\
\hline
\end{tabular}

Sumber: Analisis Data Primer, 2018

d) Insentif ekonomi bagi anggota dan konsumen Pengurus kelompok dan petani padi organik secara umum memiliki persepsi produk beras organik memiliki nilai ekonomi yang cukup baik. Peluang pasar beras organik semakin terbuka, pada musim panen terakhir (2017) harga gabah kering giling (GKP) padi organik yang dibeli Kelompok melalui Bapak Soleh sebesar Rp5.500perkg, sedangkan harga GKP pada tingkat pengepul Rp5.300perkg. Adanya selisih harga Rp200perkg merupakan insentif yang cukup baik bagi petani produsen untuk tetap memproduksi beras organik dengan mengikuti standar dan prosedur yang ada. Selain itu, untuk menjamin kualitas produk, Bapak Soleh juga memberikan benih padi organik sekitar $10 \mathrm{~kg}$ perpetani permusim tanam secara gratis untuk luasan sawah dengan rata-rata $2.000 \mathrm{~m}^{2}$.

Selain insentif ekonomi pada produsen, pengembangan beras organik juga memberi insentif ekonomi pada konsumen. Pembelian beras retail di Supermarket Rp17.000perkg untuk konsumen umum dan Rp25.000perkg untuk hotel. Sedangkan harga pembelian retail di lokasi sekretariat GATOS adalah Rp12.000perkg. GATOS dapat melakukan penjualan beras organik dalam skala retail karena telah memperoleh sertifikat PSAT sebagai syarat ketentuan perizinan penjualan retail.

e) Dukungandan perluasanjaringan (networking) Pengurus GATOS aktif melakukan perluasan jaringan pemasaran. Sampai dengan saat ini, selain memenuhi permintaan lokal seperti Magelang dan Yogyakarta, pemasaran rutin juga sudah dilakukan ke luar kota atau luar pulau seperti Semarang, Surabaya dan Kalimantan. Selain jaringan pasar, Bapak Soleh sebagai ketua kelompokjuga memiliki jaringan luas skala regional dan nasional sebagai pengamat OPT dan petani andalan sehinga proses pertukaran informasi terkait pengembangan padi organik dapat terjadi dengan cepat dan efektif. Antisipasi terhadap perubahan iklim, serangan OPT dan kekeringan dapat dimitigasi dengan cepat dan terdiiseminasikan pada anggota kelompok setelah mendapatkan informasi melalui jaringan yang dimilikinya.

f) Aktif melakukan pengujian dan sertifikasi berbagai hal terkait produk

Sebagai upaya untuk menjamin kualitas produk dan menungkatkan kepercayaan (trust) pihak terkait dan konsumen, Kelompok tani telah melakukan berbagai upaya pengujian dan sertifikasi yang melibatkan pihak eksternal. Jenis pengujian dan sertifikasi serta pihak terkait disajikan pada Tabel 4.

Melalui berbagai pengujian dan sertifikasi, kualitas beras organik dapat dipertahankan dan mendapat kepercayaan yang kuat dari konsumen. Komposisi kandungan bahan makanan yang sehat menyebabkan nasi yang berasal dari beras organik GATOS dapat bertahan dua hari tanpa perlakuan (treatment) khusus. 
Tabel 4

Jenis Pengujian dan Sertifikasi dan Pihak Terkait

\begin{tabular}{l|l|l}
\hline \multicolumn{1}{c|}{ Jenis Pengujian } & \multicolumn{1}{c|}{ Lembaga Mitra } & \multicolumn{1}{c}{ Keterangan } \\
\hline Sertifikasi beras organik & PERSADA & $\begin{array}{l}\text { Memasuki siklus sertifikasi yang } \\
\text { kedua (perpanjangan) }\end{array}$ \\
\hline $\begin{array}{l}\text { Pengujian kandungan bahan } \\
\text { beras organik }\end{array}$ & LPPT UGM & Sudah berjalan 3 tahun \\
\hline $\begin{array}{l}\text { Pengujian Pangan Segar Asal } \\
\text { Tanaman (PSAT) }\end{array}$ & Kementerian Pertanian & Sudah berjalan 1 tahun \\
\hline
\end{tabular}

Sumber: Analisis data primer, 2018

g) Pemanfaatan Teknologi Informasi dan Komunikasi (TIK)

Eksistensi dan kiprah GATOS mulai dikenal luas oleh berbagai pihak dan konsumen potensial setelah informasi yang terkait dengan GATOS dan produk beras organik ditampilkan dalam website Dinas Pertanian dan Tanaman Pangan Provinsi Jawa Tengah. Penyajian informasi profil produk dan kontak person ternyata cukup efektif untuk mempromosikan produk GATOS. Pada saat ini konsumen dapat melakukan komunikasi dengan kelompok baik secara langsung maupun dengan bantuan TIK sehinga proses komunikasi lebih efektif dan cepat. Pada masa mendatang pengelolaan sistem informasi yang dikelola secara langsung oleh GATOS akan sangat potensial untuk membangun jaringan yang lebih luas yang mencakup ragional, nasional maupun internasional. Selain media standar seperti official website, juga dapat dikembangkan melalui berbagai media sosial (social network media).

h) Dukungan potensi sumberdaya alam dan lingkungan

Sumberdaya alam yang tersedia cukup baik utamanya kualitas dan kondisi lahan pertanian. Ketersediaan air sepanjang tahun dan lokasi di daerah pegunungan yang jauh dari kawasan industri juga merupakan faktor keunggulan di wilayah Sawangan karena potensi pencemaran air dapat diminimalisasi sehingga proses produksi beras organik menjadi lebih efektif dan terjamin.

\section{Problematika dan Faktor Penghambat}

Pengembangan beras organik pada kelompok tani GATOS maupun pada pertanian organik lainnya masih menghadapi berbagai problematika yang mirip yang memerlukan strategi untuk dan solusi pada masa-masa mendatang. Problematika pengembangan padi organik antara lain mencakup hal-hal sebagai berikut:

a) Standarisasi kualitas produk antarkelompok tani

Standarisasi kualitas produk antara kelompok tani masih belum seragam. Kondisi sumberdaya alam yang berbeda dan juga kapasitas serta kualitas SDM pengelola yang beragam serta efektivitas leadership dalam kelompok yang juga bervariasi menyebabkan kualitas produk juga masih relatif beragam. Keragaman kualitas produk menjadi kendala jika dikaitkan dengan peluang pemenuhan pasar skala besar baik di tingkat lokal, regional, nasional atau bahkan internasional.

b) Fluktuasi harga antarkelompok tani

Tingkat harga produk di masing-masing kelompok juga masih beragam, hal ini terkait dengan struktur biaya yang masih beragam dan juga potensi pasar masingmasing yang juga beragam. Pemenuhan permintaan pasar atas produk beras organik yang makin membesar pada masa mendatang memerlukan perbedaan harga yang kecil antarkelompok sehingga memudahkan proses penanganan atau handling dan juga pembentukan harga bersama dengan partner strategis. 
c) Benih organik tidak tersedia di pasar Salah satu problem yang cukup serius adalah kualitas benih untuk padi organik. Sampai saat ini belum ada korporasi atau produsen benih yang memasarkan benih padi organik yang berkualitas tinggi atau bersertifikat. Benih padi yang tersedia di pasar merupakan benih padi konvensional. Benih sebagai bahan dasar tanaman menentukan kualitas produk yang akan dihasilkan sehingga ketersediaan benih padi organik menjadi isu yang sangat strategis.

Pada kasus pengembangan beras organik GATOS di kelompok tani yang dipimpin Bapak Soleh, untuk menjamin kualitas beras organik, benih padi organik disediakan oleh Bapak Soleh. Proses pengembangan benih padi organik di lakukan lahan milik pribadi Bapak Soleh atau membeli produk dari anggota kelompok tani yang memiliki kemampuan menghasilkan benih padi organik yang berkualitas baik.

Selain problematika yang dihadapi dalam pengembangan beras organik standar nasional, problematika yang dipandang menghambat pengembangan sertifikasi oganik bestandar internasional yang umumnya diarahkan untuk memenuhi kebutuhan pasar ekspor beras organik dapat disajikan pada uraian berikut:

a) Insentif ekonomi yang belum jelas

Sampai dengan saat ini, petani pelaku usaha beras organik maupun kelompok tani belum mendapat informasi yang komprehensif terkait dengan insentif ekonomi jika produk yang dihasilkan dapat memenuhi standar internasional dan dapat diekspor ke negara-negara konsumen.

b) Kerumitan proses dan standarisasi produk Berdasarkan informasi yang diperoleh oleh sebagain pengurus kelompok, diperspesikan oleh para petani bahwa proses dan standardisasi produk untuk skala internasional lebih rumit dan banyak prasyarat yang nampaknya sulit dipenuhi oleh para petani produsen karena usahanya bersifat individu bukan sebagai korporasi di bawah satu manajemen. c) Jaminan dan kerumitan prosedur ekspor produk

Selain kerumitan proses dan standar produksi beras organik sesuai dengan standar internasional, kerumitan yang lain yang dipersepsikan rumit bagi kelompok tani dan petani adalah komponen dan prosedur quality control yang berat, proses panjang yang berimplikasi pada risiko kerusakan produk dan potensi komplain dari konsumen tinggi, serta pembiayaan yang mahal yang sulit ditanggung oleh asosiasi kelompok tani. Kelompok tani atau asosiasi harus membayar produk pada petani dengan cara cash, jika model ekspor dengan letter of credit (LC) umumnya perlu waktu sehingga ada problem finansial bagi kelompok tani atau asosiasi produsen organik.

\section{Peluang dan Strategi Menuju Sertifikasi Internasional}

Pertanian organik mempunyai aturan yang baku dengan persyaratan yang sudah terstruktur berupa dokumen panduan yang harus diikuti oleh petani untuk mendapatkan sertifikasi organik. Petani harus mengetahui dengan saksama definisi pertanian organik dan bagaimana cara menjalankannya. Hal ini menjadi penting sebagai kebutuhan yang mendasar bagi petani untuk menjalankan pertanian organik. Hasil analisis tentang kesesuaian standar usahatani padi organik dengan praksis usahatani di lapangan disajikan pada Tabel 5.

Petani padi organik di Sawangan Magelang semuanya sudah memahami bahwa pertanian organik tidaklah menggunakan input berupa pupuk dan pestisida kimia sehingga pertanian padi organik sudah mengikuti kaidah pertanian organik yang sebenarnya. Status pertanian berupa proses organik dan full organik ditentukan oleh kondisi petani sudah atau belum menerima sertifikat organik bagi produknya. Sertifikat organik yang dapat diterima oleh petani bisa didapatkan ketika proses usaha tani padi mereka sudah sepenuhnya organik. Petani yang masuk ke dalam kategori proses organik adalah petani 
yang masih mengusahakan kondisi lahan dan sistem budidayanya kearah organik yaitu mengondisikan lahan berupa pemberian barrier terhadap lahan lain yang non-organik, pengaplikasian sistem filter air yang masuk ke lahan sawah organik, serta pengembalian nutrisi dan unsur hara tanah melalui berbagai input alami. Sebagian besar petani padi organik di Sawangan Magelang sudah masuk ke dalam kategori sepenuhnya organik (full organic).

Tabel 5

Kesesuaian Standar Usahatani Padi Organik dengan Aplikasinya di Sawangan

\begin{tabular}{l|l|l}
\hline \multicolumn{1}{c|}{ Komponen } & \multicolumn{1}{c}{ Aspek } & \multicolumn{1}{c}{ Proporsi Responden (\%) } \\
\hline \multirow{4}{*}{ Pengetahuan definisi organik } & Tanpa pestisida kimia (\%) & 0 \\
\cline { 2 - 3 } & Tanpa pupuk kimia (\%) & 0 \\
\cline { 2 - 3 } & Tanpa keduanya (\%) & 100 \\
\hline \multirow{2}{*}{ Status pertanian } & Proses organik (\%) & 17 \\
\cline { 2 - 3 } & Full organik (\%) & 83 \\
\hline \multirow{2}{*}{ Bibit bersertifikat organik } & Tanpa input kimia (\%) & 87 \\
\cline { 2 - 3 } & Dengan input kimia (\%) & 13 \\
\hline \multirow{5}{*}{ Pencatatan usahatani } & Ya (\%) & 30 \\
\cline { 2 - 3 } & Tidak (\%) & 70 \\
\cline { 2 - 3 } & Tidak Tahu (\%) & 0 \\
\hline \multirow{2}{*}{ Sumber air bebas kontaminan } & Ya (\%) & 4 \\
\cline { 2 - 3 } & Tidak (\%) & 96 \\
\cline { 2 - 3 } & Ya (\%) & 37 \\
\cline { 2 - 3 } & Tidak (\%) & 9 \\
\cline { 2 - 3 } & Tidak Tahu (\%) & 35 \\
\hline
\end{tabular}

Sumber: Analisis data primer, 2018

Sebagian besar petani padi organik sudah memahami bahwa pengertian atau definisi pertanian organik tidak menggunakan input pupuk maupun pestisida kimia. Meskipun demikian, masih terdapat beberapa petani yang masih menggunakan input kimia terutama pupuk dengan dalih bahwa kandungan pupuk kimia maupun pupuk hayati adalah sama yaitu ingin menambahkan unsur N, P, K atau yang lainnya ke dalam tanah.

Banyak petani yang belum menggunakan benih atau bibit yang bersertifikasi organik. Hal ini disebabkan oleh akses yang cukup sulit untuk mendapatkan bibit yang bersertifikat organik serta harga yang harus ditebus cukup mahal. Akan tetapi, dalam sistem pertanian organik masih memperbolehkan bibit yang belum bersertifikat organik asalkan tidak menggunakan bibit hasil rekayasa genetika atau genetically modified organism (GMO).
Pencatatan usaha tani menjadi penting sebagai salah satu penilaian ketika akan mengajukan sertifikasi organik. Sebagian besar petani belum melakukan pencatatan usaha tani sehingga tidak ada catatan historis input apa saja yang dimasukkan ke dalam lahan pada proses budidaya padi organik. Tidak adanya pencatatan usahatani ini juga berdampak pada kurangnya pengetahuan petani terhadap kondisi manajemen dan finansial usaha tani padi organik mereka. Petani masih berpikir bagaimana cara memproduksi yang sebesar-besarnya bukan berorientasi pada memaksimalkan keuntungan.

Salah satu input penting dalam kegiatan usaha tani adalah air, terutama dalam budidaya padi. Budidaya padi organik sangat memperhatikan kualitas air yang digunakan. Air ini harus bebas dari kontaminan karena air sering dimasukkan ke dalam lahan pertanian organik 
Subejo, Irham, Pinjung Nawang Sari, Arif Wahyu Widada, Azizatun Nurhayati, Laksmi Yustika Devi, dan Esti Anatasari $*$ Problematika Pengembangan Padi Organik di ...

yang tidak langsung bersumber dari sumber utama air tersebut. Keadaan ini memungkinkan air yang masuk ke dalam lahan yang diusahakan sebagai pertanian organik masuk terlebih dahulu ke lahan petani lain yang tidak diusahakan secara organik. Keadaan ini menuntut petani organik membuat treatment atau filter air sebelum dimasukkan ke lahan. Sebagian besar petani sudah menerapkan hal ini.

Dengan mempertimbangkan kondisi eksisting, berbagai peluang dan potensi serta faktor-faktor pendorong, upaya-upaya dan strategi yang perlu dilakukan untuk pengembangan padi organik di Sawangan Magelang menuju sertifikasi internasional antara lain sebagai berikut:

a) Inovasi Diversifikasi Produk

GATOS memberikan respon yang cukup taktis dalam melihat berbagai peluang dan permintaan konsumen akan beras organik melaui pengembangan diverasifikasi produk beras organik. Diversifikasi antara lain dilakukan dengan membuat berbagai jenis produk, yaitu beras putih, beras merah, dan beras hitam. Petani juga pengembangan beberapa varietas unggulan antara lain: mentik wangi, mentik susu, IR 64, beras hitam, beras merah. Sedangkan inovasi dalam kemasan juga dilakukan dengan membuat kemasan yang beragam, yaitu kemasan $2 \mathrm{~kg}$ dan kemasan $5 \mathrm{~kg}$. GATOS juga melakukan inovasi pada jenis prosesing yaitu beras pecah kepala dan beras dengan pengolahan lengkap. Proses pengemasan atau packaging juga telah dilakukan diversifikasi yaitu packaging biasa dan vacuum packaging.

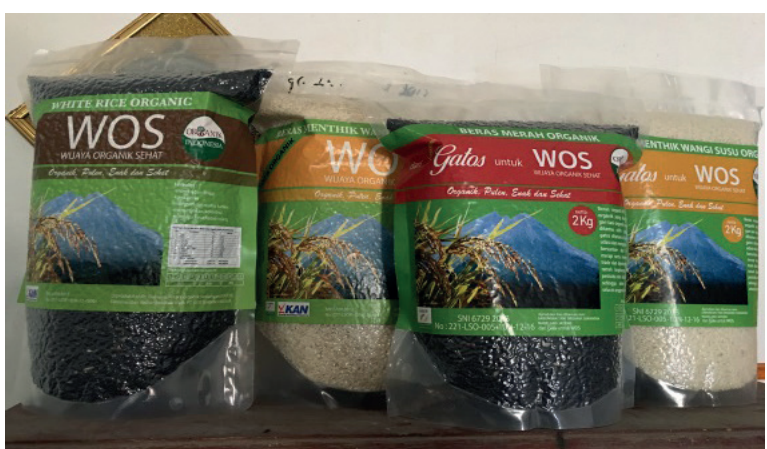

Gambar 3

Diversifikasi Produk GATOS

(Sumber: Dokumentasi pribadi, 2018)

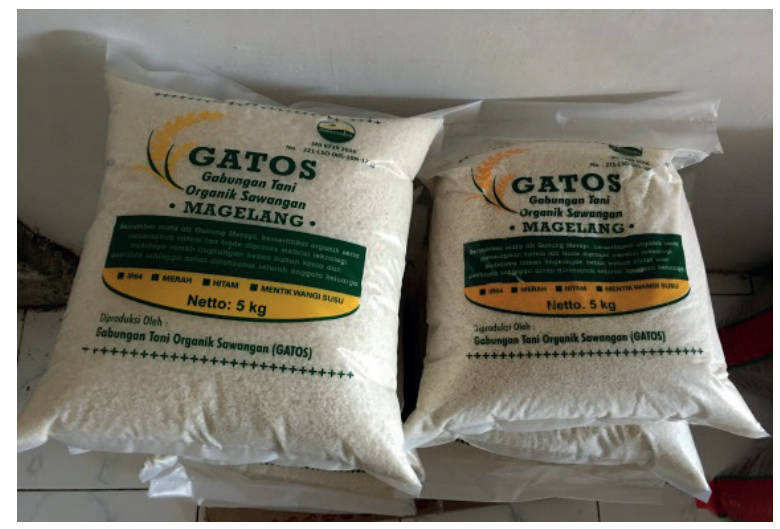

Gambar 4

Kemasan Beras $5 \mathrm{Kg}$

(Sumber: Dokumentasi pribadi, 2018)

b) Standardisasi produk dengan sertifikat produk segar asal tumbuhan (PSAT)

GATOS telah melakukan pengujian dan sertifikasi melalui Kementerian Pertanian untuk pengujian Produk Segar Asal Tumbuhan (PSAT) dimana manfaat dari pengujian ini adalah jaminan kualitas produk dan memungkinkan produk dapat dijual dalam skala retail. Strategi ini sangat penting dengan tujuan memperoleh insentif ekonomi yang lebih tinggi dan trade mark GATOS juga sudah dikenal publik dibandingkan menjual pada pedagang perantara yang akan mengemas dan menjual beras organik dangan trade mark yang lain.

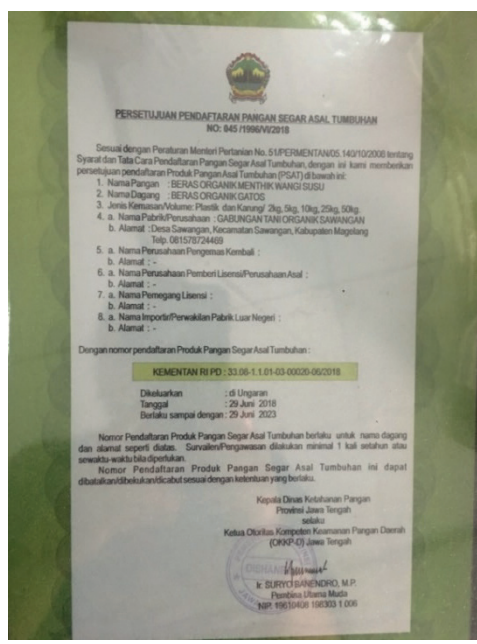

Gambar 5

Sertifikat PSAT untuk GATOS

(Sumber: Dokumentasi pribadi, 2018) 
c) Perintisan pengembangan dan modernisasi alat mesin pemroses beras

Kementerian Pertanian dan Dinas Pertanian Kabupaten Magelang saat ini sedang dalam proses memfasilitasi GATOS untuk melakukan kerjasama dengan lembaga donor yaitu Asian Development Bank-International Fund for Agricultural Development (ADB-IFAD) terkait dengan perbaikan pengelolaan dan prosesing beras organik sehingga kualitas menjadi lebih baik dan diharapkan dapat memenuhi permintaan standar yang lebih tinggi (termasuk standardisasi internasional). Sampai saat ini sudah dilakukan feasiblity study dan juga field visit dari expert ADB-IFAD untuk proses pengadaan mesin pemroses beras yang memiliki standardisasi tinggi.

Proses penanganan dan pengolahan gabah menjadi beras yang dilakukan GATOS masih menggunakan mesin dan teknologi yang konvensional. Kondisi ini juga menyebabkan standardisasi kualitas beras juga kurang optimal, selain kadar pecah beras yang tinggi juga kebersihan beras masih menjadi tantangan. Sebagai contoh lantai jemur yang ada masih konvensional yang tergantung pada ketersediaan sinar matahari dan pembersihan dan pemilahan beras dengan cara manual.

Modernisasi mesin pemroses beras dirancang untuk dapat memperbaiki kualitas dan mereduksi potensi dan resiko misalnya dengan adanya mesin pengering maka tidak ada hambatan ketika proses dilakukan musim penghujan dan dengan mesin pemisah atau sortasi menggunakan sensor maka kebersihan beras dari kotoran akan lebih sempurna.

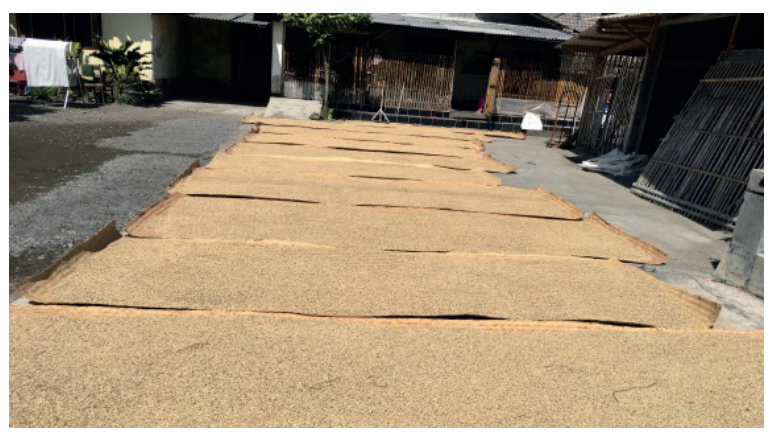

Gambar 6

Pengeringan Gabah Manual

(Sumber: Dokumentasi pribadi, 2018)

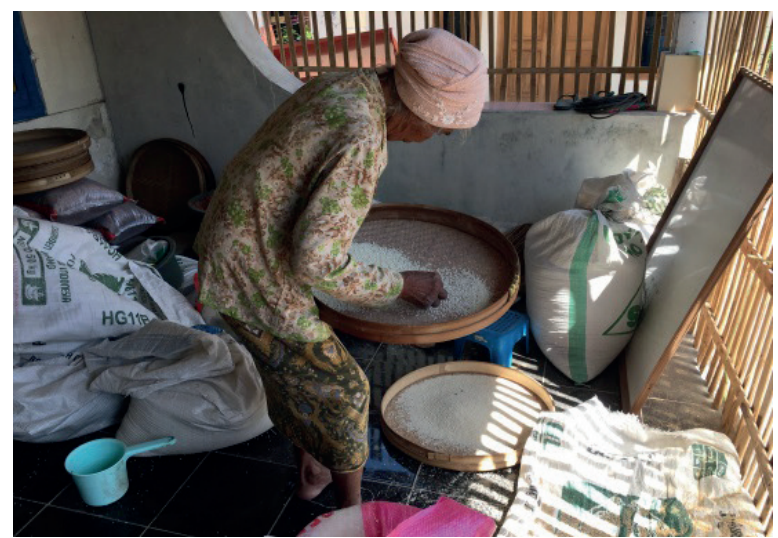

Gambar 7

Sortasi Gabah Manual

(Sumber: Dokumentasi pribadi, 2018)

\section{SIMPULAN}

Pengembangan padi organik di Sawangan Magelang mengalami peningkatan yang signifikan dan secara umum tingkat produktivitas semakin membaik mendekati produktivitas padi konvensional sehingga pendapatan dan keuntungan yang diterima para petani padi organik semakin meningkat. Faktor pendukung pengembangan padi organik di Sawangan Magelang mencakup: inisiasi sistem produksi padi sehat melalui dukungan dan praktik SLPHT, kepemimpinan transformatif dan inovatif dalam kelompok tani, dukungan pemangku kepentingan terkait insentif ekonomi bagi anggota dan konsumen, dukungan dan perluasan jaringan (networking), aktif melakukan pengujian dan sertifikasi berbagai hal terkait produk, pemanfaatan teknologi informasi dan komunikasi dan dukungan potensi sumberdaya alam dan lingkungan

Permasalahan yang dihadapi dalam pengembangan beras organik antara lain: standarisasi kualitas produk antarkelompok tani masih lemah, fluktuasi harga antarkelompok tani, dan ketidaktersediaan benih organik di pasar.

Peluang dan strategi pengembangan padi organik di Sawangan Magelang menuju sertifikasi internasional mencakup: inovasi diversifikasi produk, standardisasi produk dengan sertifikat produk segar asal tumbuhan (PSAT), perintisan pengembangan, dan modernisasi alat mesin pemroses beras yang berkualitas tinggi. 


\section{DAFTAR PUSTAKA}

Aziez, A.F., Indradewa, D., Yudono, P dan Hanudin, E. 2014. Kehijauan Daun, Kadar Khlorofil, Dan Laju Fotosintesis Varietas Lokal Dan Varietas Unggul Padi Sawah Yang Dibudidayakan Secara Organik Kaitannya Terhadap Hasil Dan Komponen Hasil, AGRINEÇA 14(2 ):114-127.

Bandura, A. 1977. Social Learning Theory. General Learning Press. New York.

Camat Sawangan. 2018. Profil Kecamatan Sawangan. LP3M. (http://lp3m. ummgl.ac.id/wp-content/uploads / 2015/04/10-CAMAT-SAWANGAN. pptx). Diakses pada tanggal 15 Oktober 2018.

Coleman, J.S. 1988. Social Capital In The Creation of Human Capital. Supplement: Organizations And Institutions: Sociological And Economic Approaches To The Analysis of Social Structure. American Journal of Sociology 94:S95-S120.

David, W. dan Ardiansyah. 2017. Organic Agriculture In Indonesia: Challenges And Opportunities. Org. Agr 7:329338.
Jahroh,S.2010. OrganicFarming Development in Indonesia: Lessons Learned from Organic Farming in West Java and North Sumatra. Innovation and Sustainable Development in Agriculture and Food (ISDA) Montpellier. June 28-30: 1-11.

Ruslanjari, D., A.B. Kurnia dan Permana, R.S. 2017. Enhancing Capacity of Local Community Toward Agricultural Drought In Ploso Village Yogyakarta Based On Vulnerability Assessment. Jurnal Tekno Sains 7(1):1-82.

Setiawan, M. 2013. Peta Adminsitrasi Kabupaten Magelang. (http:// referensigeography.blogspot. com/2013/05/peta-administrasikabupaten-magelang.html). Diakses pada tanggal 7 Oktober 2018.

Supyandi, D., Sukayat, Y., Arari, M dan Heryanto. 2014. Beras Organik: Upaya Meningkatkan Daya Saing Pertanian (Studi Kasus Di Kabupaten Bandung, Propinsi Jawa Barat. Sustainable Competitive Advantage (SCA) JP Journal and Proceeding FEB UNSOED 4(1):190-201. 